\title{
Effect of Methotrexate on Neuroepithelium in the Rat Fetal Brain
}

\author{
Jing SUN ${ }^{1,2)}$, Akihiko SUGIYAMA ${ }^{1,2) *}$, Shota INOUE $^{1)}$, Takashi TAKEUCHI ${ }^{1,2)}$ and Satoshi FURUKAWA ${ }^{3)}$ \\ ${ }^{1)}$ Courses of Veterinary Laboratory Medicine, School of Veterinary Medicine, Faculty of Agriculture, Tottori University, 4-101 \\ Koyama-cho Minami, Tottori, Tottori 680-8553, Japan \\ 2) United Graduate School of Veterinary Science, Yamaguchi University, 1677-1 Yoshida, Yamaguchi 753-8515, Japan \\ ${ }^{3)}$ Toxicology and Environmental Science Department, Biological Research Laboratories, Nissan Chemical Industries, Ltd., 1470 \\ Shiraoka, Minamisaitama, Saitama 349-0294, Japan
}

(Received 17 September 2013/Accepted 26 October 2013/Published online in J-STAGE 8 November 2013)

ABSTRACT. Pregnant rats were treated with $30 \mathrm{mg} / \mathrm{kg}$ of methotrexate (MTX) on gestation day 13, and fetal brains were examined histopathologically from 6 to $48 \mathrm{hr}$ after the treatment. In the telencephalon of the control group, there were few pyknotic neuroepithelial cells throughout the experimental period. Six hr after MTX treatment, several pyknotic neuroepithelial cells scattered throughout the telencephalic wall. At $12-36 \mathrm{hr}$, pyknotic neuroepithelial cells increased significantly and were diffusely distributed throughout the telencephalic wall. Neuroepithelial cells were eliminated and showed sparse cell density at $36 \mathrm{hr}$ in the telencephalon. Almost all fetuses died at $48 \mathrm{hr}$. Most of the pyknotic neuroepithelial cells were positively stained by the TUNEL method and positive for cleaved caspase-3. While mitotic and phospho-histone H3-positive neuroepithelial cells were located along the ventricular layer of telencephalon in the control group, they were rarely observed in the same region at 6-36 hr in the MTX-treated group. MTX induced few pyknotic changes to neuroepithelial cells in the metencephalon, compared to other parts of brain. The distribution of apoptotic neuroepithelial cells and the time-course changes of the indices of apoptotic and mitotic neuroepithelial cells were different from those of other DNA-damaging chemicals reported previously. The difference may reflect the disparity in mechanisms of apoptosis and the inhibition of cell proliferation in neuroepithelial cells induced by MTX. To our knowledge, this is the first report demonstrating histopathological findings of fetal brain damage induced by MTX. KEY WORDS: apoptosis, brain, fetus, methotrexate, neuroepithelial cell.

doi: 10.1292/jvms.13-0457; J. Vet. Med. Sci. 76(3): 347-354, 2014

A folate antagonist, methotrexate (MTX), inhibits dihydrofolate reductase that reduces dihydrofolate to tetrahydrofolate. MTX therefore limits the availability of one-carbon fragments necessary for the synthesis of purines and interferes with the conversion of deoxyuridylate to thymidylate in the synthesis of DNA and cell proliferation $[9,14,26]$. MTX is known to induce apoptosis, and the mechanism of MTX-induced apoptosis is considered to be associated with the up-regulation of p53 and p21 proteins [22, 36], repression of the induction of c-Jun N-terminal kinase (JNK) activity, expression of the CD95 receptor/ligand system [27] and reactive oxygen species $[11,36]$.

MTX has been used in the treatment of malignancy, autoimmune and inflammatory diseases and gestational trophoblast disease [3, 4, 9]. MTX is also used as an abortifacient, both for the voluntary termination of pregnancy and for the medical management of ectopic pregnancy [24]. Medical treatment protocols for MTX were established in the 1980s and have become a widely accepted primary treatment for unruptured ectopic pregnancy $[25,32,33]$. In humans, MTX

*Correspondence to: SugiYama A., Courses of Veterinary Laboratory Medicine, School of Veterinary Medicine, Faculty of Agriculture, Tottori University, 4-101 Koyama-cho Minami, Tottori 680-8553, Japan. e-mail: sugiyama@muses.tottori-u.ac.jp

(C)2014 The Japanese Society of Veterinary Science

This is an open-access article distributed under the terms of the Creative Commons Attribution Non-Commercial No Derivatives (by-ncnd) License $<$ http://creativecommons.org/licenses/by-nc-nd/3.0/>. embryopathy results from failed pregnancy termination with MTX or when mothers who are taking MTX for medical reasons become pregnant inadvertently $[1,2,14,35]$. The anomalies of MTX embryopathy include nervous system anomalies, growth deficiency, craniofacial deformities and skeletal defects $[14,26]$. As the central nervous system anomalies in MTX embryopathy, alobar/semilobar holoprosencephaly [2, 35], cerebellar hypoplasia [35], agenesis of the corpus callosum [35] and microcephaly [1, 8] have been reported. However, there are few reports to examine the brain anomalies in MTX embryopathy histopathologically, and their detailed histopathogical findings or their detailed pathogenesis remain unclear. In experimental animals, prenatal MTX exposure reportedly induced anomalies of the brain in chicken [44] and rabbits [16]. In rabbit, MTX administration on gestation days (GD) 10-12 or GD 12 caused hydrocephalus $[5,16]$. However, there are few reports to date describing damage to the fetal brain following MTX administration to dams, and detailed effects of prenatal MTX treatment on fetal brain have been not completely elucidated even in experimental animals. Therefore, in the present study, we examined histopathologically the time-dependent changes of fetal brain following MTX administration to their dams on GD 13 to clarify pathogenesis of MTX-induced brain anomalies in fetuses.

\section{MATERIALS AND METHODS}

Animals: All experiments were performed using female Wistar Imamichi rats, 9-10 weeks of age, 218.45 $\pm 2.09 \mathrm{~g}$ 
Table 1. Effects of methotrexate on rat fetuses

\begin{tabular}{llcccc}
\hline & Treatment & No. of dams & Total No. of live fetuses & Living fetuses per litter & Dead fetus ratio (\%) \\
\hline $6 \mathrm{hr}$ & Control & 4 & 58 & $14.59 \pm 0.50$ & $9.03 \pm 3.03$ \\
& MTX & 4 & 57 & $14.25 \pm 0.63$ & $3.14 \pm 1.82$ \\
\multirow{3}{*}{$12 \mathrm{hr}$} & Control & 4 & 56 & $14.00 \pm 0.41$ & $7.93 \pm 3.00$ \\
& MTX & 4 & 63 & $15.75 \pm 2.50$ & $15.92 \pm 10.67$ \\
\multirow{3}{*}{$36 \mathrm{hr}$} & Control & 4 & 58 & $14.50 \pm 1.44$ & $7.63 \pm 4.81$ \\
& MTX & 4 & 57 & $14.25 \pm 0.95$ & $6.48 \pm 4.44$ \\
$48 \mathrm{hr}$ & Control & 4 & 62 & $15.50 \pm 1.19$ & $3.58 \pm 3.58$ \\
& MTX & 4 & 44 & $11.00 \pm 0.41^{*}$ & $30.30 \pm 5.41^{* *}$ \\
& Control & 4 & 56 & $14.00 \pm 1.00$ & $4.73 \pm 3.15$ \\
& MTX & 4 & 1 & $0.25 \pm 0.25 \dagger \dagger \dagger$ & $98.53 \pm 1.48^{* * *}$ \\
\hline
\end{tabular}

Values are expressed as means $\pm \mathrm{SE} . *, * *, * * *$ Significantly different from control at $P<0.05, P<0.01, P<0.001$, respectively (Student's $t$-test). $\uparrow \dagger \uparrow$ : Significantly different from control at $P<0.001$ (Welch's $t$-test).

(mean $\pm \mathrm{SE}$ ) in weight, and obtained from the Institute of Animal Reproduction (Kasumigaura, Japan). The animals were reared in a room with the temperature controlled at 22 $\pm 2{ }^{\circ} \mathrm{C}$, humidity at $50 \pm 5 \%$, with ventilation 11 times per $\mathrm{hr}$, lighting at 12:12-hr light/dark cycle (light cycle, 7:0019:00) and given standard chow (CE-2; Nihon Clea, Tokyo, Japan). The present experiments were performed following the provisions approved by the Animal Research Committee of Tottori University.

Experimental design: A total of 40 animals were divided into 2 groups as follows: (1) saline-treated control rats $(\mathrm{n}=20),(2)$ MTX-treated rats $(\mathrm{n}=20)$. MTX (Pfizer Japan Inc., Tokyo, Japan) was dissolved in saline. Day 0 of gestation (GD 0) was designated as the day when the presence of a vaginal plug was identified. The rats received intraperitoneal injections (i.p.) with MTX (30 mg/kg body weight) or saline (the control) on GD 13. The specific timing of MTX administration was selected, because the injection of DNA damaging chemicals, such as ethylnitrosourea (ENU) [19-21], 6-mercaptopurine (6-MP) [17], busulfan [30], T-2 toxin [34], 1- $\beta$-D-arabinofuranosylcytosine (Ara-C) [43], 5-azacytidine $(5 \mathrm{AzC})[39,40]$ and 5-Fluorouracil (5-Fu) [42], on GD13 induced apoptosis in neuroepithelial cells of telencephalon in rat fetal brain. The dose level in the present study was decided, because this dose was equivalent to $10 \%$ of the LD50 in intraperitoneal injection in rats or $15-30 \%$ of dosage used in high-dose cancer therapy in human [12, 15, 23]. Fetus samples were collected under pentobarbital anesthesia (100 mg/kg, i.p.) 6, 12, 24, 36 and $48 \mathrm{hr}$, respectively, after MTX administration. They were removed from the uterus and weighed, and their body lengths were measured.

Histopathological examination: For histopathological examination, all fetuses were fixed in $10 \%$ neutral buffered formalin and then embedded in paraffin. The tissues of telencephalon, diencephalon, mesencephalon and metencephalon in 12 fetal brain samples per group consisted of 3 fetuses ramdomly selected per dam in each group were sectioned at $2 \mu \mathrm{m}$ thickness, stained with hematoxylin and eosin and examined with light microscopy. The number of pyknotic cells or mitotic cells was counted from over 1,000 neuroepithelial cells in the telencephalon, diencephalon, mesencephalon and metencephalon for each fetus by light microscopy, and the pyknotic index and mitotic index were calculated as the percentage of pyknotic cells or mitotic cells from out of the total number of neuroepithelial cells counted.

TUNEL method: DNA-fragmented neuroepithelial cells in telencephalon were detected by terminal deoxynucleotidyltransferase (TdT)-mediated deoxyuridine triphosphatedigoxigenin (dUTP) nick-end labeling (TUNEL), which was performed using an in situ apoptosis detection kit (Trevigen, Inc., Gaithersburg, MD, U.S.A.). The number of TUNELpositive cells was obtained from over 1,000 neuroepithelial cells in the telencephalon for each fetus by light microscopy, and the TUNEL-index was calculated as the percentage of TUNEL-positive cells out of the total number of neuroepithelial cells counted.

Immunohistochemical examinations of rat fetuses: Immunohistochemical staining was performed by a labeledpolymer method using Histofine Simple Stain MAX-PO (R) (Nichirei, Tokyo, Japan). To retrieve the antigen, tissue sections for the detection of cleaved caspase-3 antigen were immersed in citrate buffer, pH 6.0 (Dako, Glostrup, Denmark) and autoclaved for $15 \mathrm{~min}$ at $121^{\circ} \mathrm{C}$; and tissue sections for the detection of phospho-histone $\mathrm{H} 3$ antigen were immersed in citrate buffer, pH 6.0 (Dako) and microwaved for $15 \mathrm{~min}$. Endogenous peroxidase activity was quenched by immersing the sections in 3\% hydrogen peroxide in methanol for 15 min. The sections were incubated with the cleaved caspase-3 rabbit polyclonal antibody (1:300 dilution; Cell Signaling Technology, Inc., Danvers, MA, U.S.A.) at $4^{\circ} \mathrm{C}$ overnight; and the sections were incubated with the phospho-histone H3 rabbit monoclonal antibody (1:1,500 dilution; Abcam, Tokyo, Japan) for $30 \mathrm{~min}$ at room temperature. Then, these sections were treated with Histofine Simple Stain MAX-PO (R) (Nichirei) for $30 \mathrm{~min}$ at room temperature. They were exposed to a 3,3'-diaminobenzidine solution containing hydrogen peroxide (Nichirei) to facilitate a peroxidase color reaction and then counterstained with Mayer's hematoxylin. The number of cleaved caspase-3- or phospho-histone H3positive cells was counted from over 1,000 neuroepithelial cells in the telencephalon for each fetus by light microscopy, and the cleaved caspase-3- or phospho-histone H3-index was calculated as the percentage of cleaved caspase-3- or phospho-histone H3-positive cells out of the total number of 


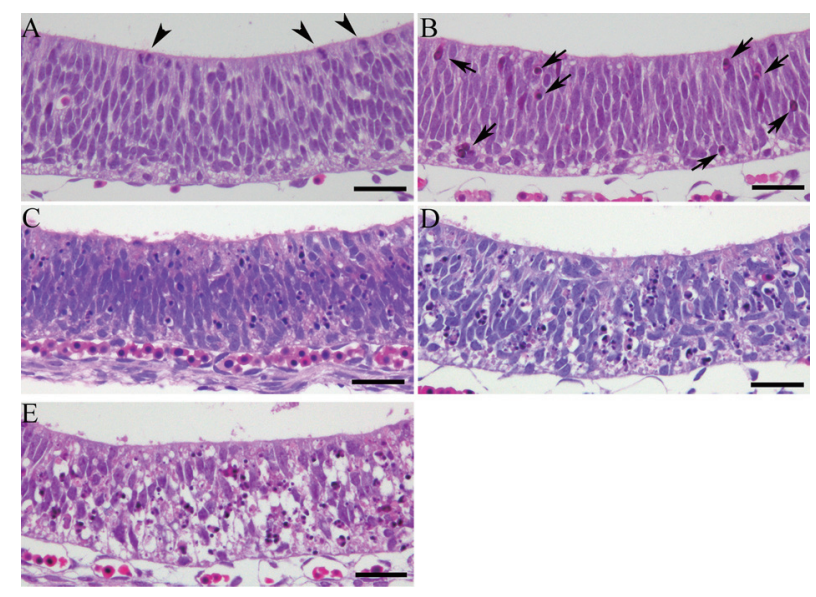

Fig. 1. Histopathological findings of telencephalic wall of rat fetal brain in the control group $6 \mathrm{hr}$ after treatment (A) and the MTXtreated group at $6(\mathrm{~B}), 12(\mathrm{C}), 24(\mathrm{D})$ and $36 \mathrm{hr}(\mathrm{E})$, respectively. (A) Arrowheads indicate mitotic cells. (B) Arrows indicate pyknotic cells. Bar $=30 \mu \mathrm{m}$.

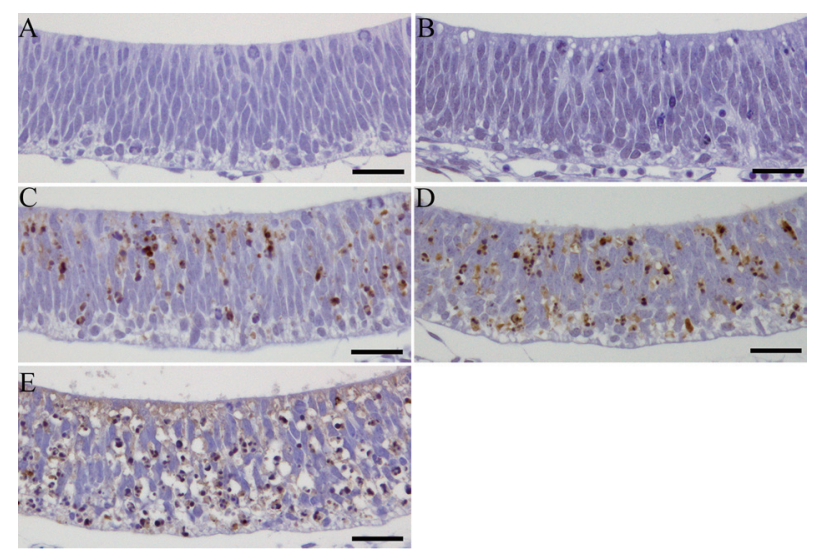

Fig. 3. TUNEL-positive cells in telencephalic wall of rat fetal brain in the control group $6 \mathrm{hr}$ after treatment (A) and the MTX-treated group at 6 (B), 12 (C), 24 (D) and $36 \mathrm{hr}(\mathrm{E})$. Bar=30 $\mu \mathrm{m}$.

neuroepithelial cells counted.

Statistical analysis: Means \pm standard error (SE) of the individual litter value was calculated. The data were analyzed with an $F$-test. When variances were homogeneous, the Student's $t$-test was performed. Welch's $t$-test was employed when variances were not homogeneous $(P<0.05) . P<0.05$, $P<0.01$ or $P<0.001$ was considered to be statistically significant.

\section{RESULTS}

Effects of MTX on rat fetuses: Six, 12 and $24 \mathrm{hr}$ after MTX treatment, there were no significant differences in the number of living fetuses per litter and the fetal mortality rates between the control group and MTX-treated group (Table 1). The number of living fetuses significantly declined, and fetal

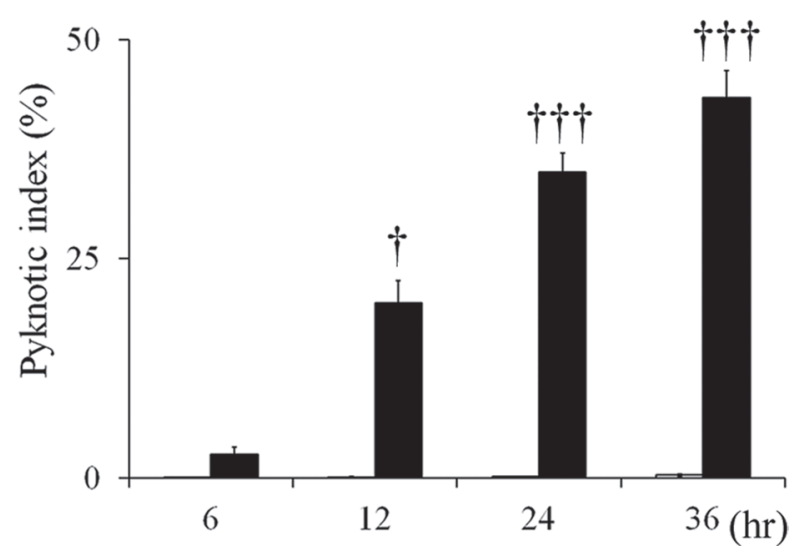

Fig. 2. Changes in the pyknotic index (\%) in telencephalic wall of rat fetal brain. Values are expressed as means \pm SE. $\uparrow$, $\uparrow \dagger \uparrow$ : Significantly different from control at $P<0.05, P<0.001$, respectively (Welch's $t$-test).

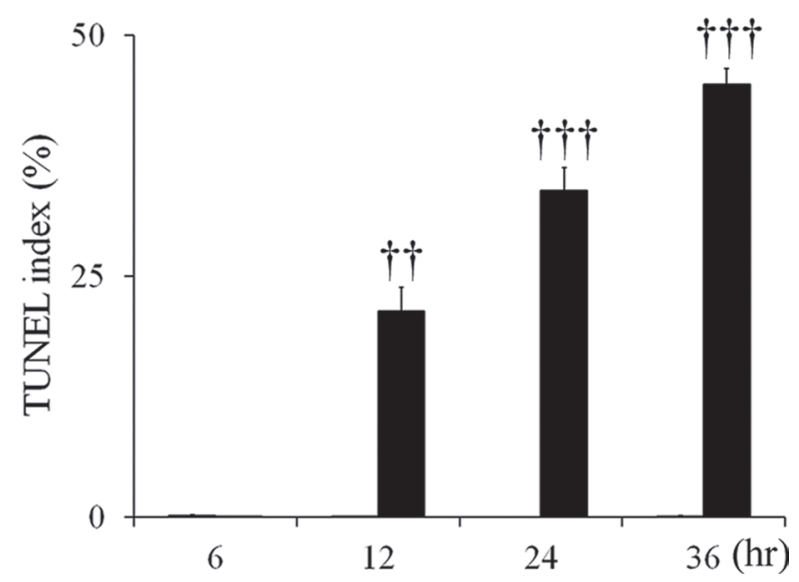

Fig. 4. Changes in the TUNEL index (\%) in telencephalic wall of rat fetal brain. Values are expressed as means \pm SE. $\dagger \dagger$, $\dagger \dagger \dagger$ : Significantly different from control at $P<0.01, P<0.001$, respectively (Welch's $t$-test).

mortality rates significantly increased at $36 \mathrm{hr}$ in the MTXtreated group, compared to those of the control group (Table 1). Almost all fetuses died by $48 \mathrm{hr}$ after MTX treatment (Table 1).

Histopathological findings of rat fetal brain: In the control group, pyknotic changes in neuroepithelial cells were rarely observed in any layers of the telencephalic wall throughout the experimental period (Figs. 1 and 2).

Six hr after treatment in the MTX-treated group, pyknotic neuroepithelial cells appeared in the telencephalic wall and scattered throughout that wall (Fig. 1B). Then, 12-36 hr after MTX treatment, pyknotic neuroepithelial cells drastically increased and were diffusely distributed throughout the telencephalic wall (Figs. 1C-1E and 2). At 36 hr, neuroepithelial cells were eliminated and showed low cell density in 


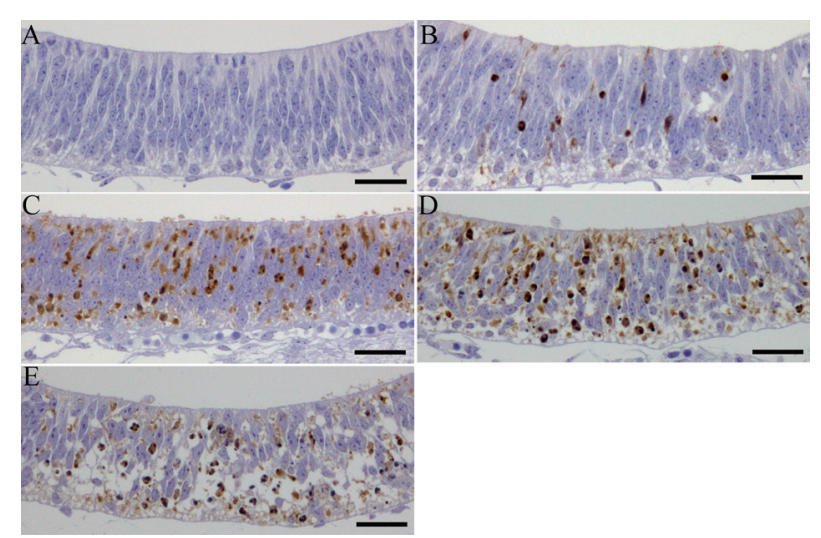

Fig. 5. Immunohistochemical expression of cleaved caspase-3 in telencephalic wall of rat fetal brain in the control group $6 \mathrm{hr}$ after treatment (A) and the MTX-treated group at 6 (B), 12 (C), 24 (D) and $36 \mathrm{hr}(\mathrm{E})$. Bar $=30 \mu \mathrm{m}$

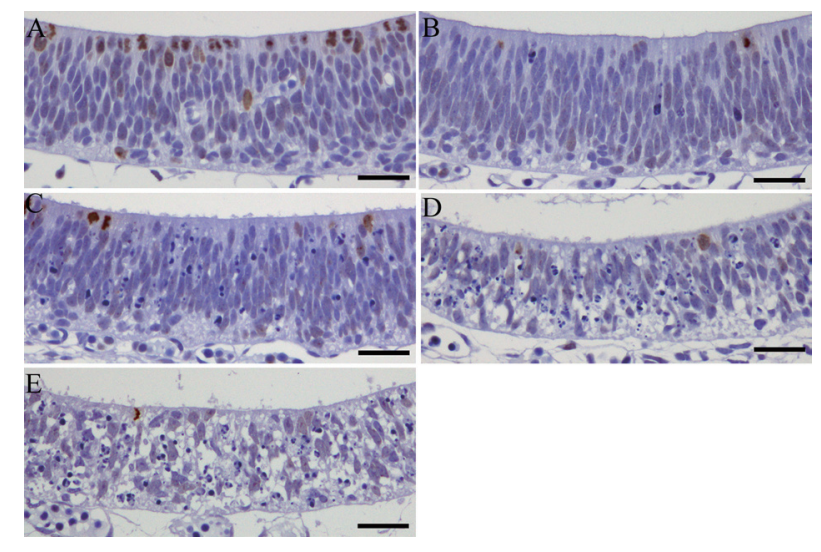

Fig. 7. Immunohistochemical expression of phospho-histone $\mathrm{H} 3$ in telencephalic wall of rat fetal brain in the control group $6 \mathrm{hr}$ after treatment (A) and the MTX-treated group at 6 (B), 12 (C), 24 (D) and $36 \mathrm{hr}$ (E), respectively. Bar=30 $\mu \mathrm{m}$.

the telencephalon of MTX-treated group (Fig. 1E). Although mitotic neuroepithelial cells were located along the ventricular layer of the telencephalic wall in the control group, they were rarely observed in the same region at 6-36 hr in the MTX-treated group (Fig. 1B-1E).

In the telencephalon of the control group, TUNEL-positive neuroepithelial cells were rarely observed in any layers of the telencephalic wall throughout the experimental period (Figs. 3A and 4). Most of the pyknotic neuroepithelial cells were positively stained by the TUNEL method at 12,24 and $36 \mathrm{hr}$ in the MTX-treated group (Fig. 3C-3E), while there were few pyknotic neuroepithelial cells positively stained by the TUNEL method at $6 \mathrm{hr}$ (Fig. 3B). In the MTX-treated group, the index of TUNEL-positive neuroepithelial cells in the telencephalic wall significantly increased at 12 and $24 \mathrm{hr}$ and peaked at $36 \mathrm{hr}$ (Fig. 4).

Cleaved caspase-3-positive neuroepithelial cells were rarely observed in the telencephalon of control group

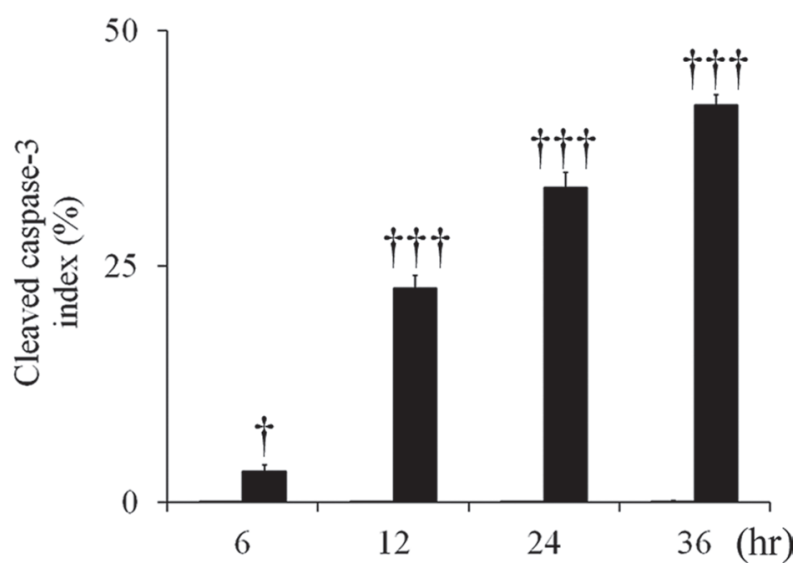

Fig. 6. Cleaved caspase-3 index. Values are expressed as means \pm SE. $\dagger$, $\dagger \dagger \uparrow$ : Significantly different from control at $P<0.05$, $P<0.001$, respectively (Welch's $t$-test).

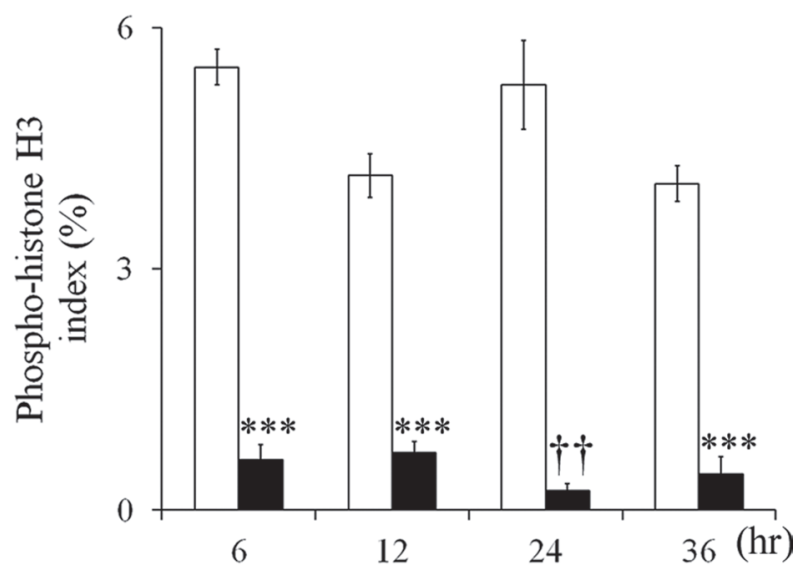

Fig. 8. Phospho-histone H3 index. Values are expressed as means \pm SE. ***: Significantly different from control at $P<0.001$ (Student's $t$-test). $\dagger \dagger$ : Significantly different from control at $P<0.01$ (Welch's $t$-test).

throughout the experimental period (Figs. 5A and 6), although in the MTX-treated group, almost all pyknotic neuroepithelial cells were immunohistochemically positive for cleaved caspase-3 throughout the experimental period (Fig. 5B-5E). In the MTX-treated group, the index of cleaved caspase-3-positive neuroepithelial cells in the telencephalon significantly increased at 6,12 and $24 \mathrm{hr}$ and peaked at 36 hr (Fig. 6).

Phospho-histone H3-positive neuroepithelial cells were located along the ventricular layer of the telencephalic wall in the control group, while there were fewer phospho-histone $\mathrm{H} 3$-positive cells at 6-36 hr in the same region of the MTXtreated group than in the control group (Fig. 7A-7E). The index of phospho-histone H3-positive neuroepithelial cells in telencephalon decreased significantly at $6 \mathrm{hr}$ compared with the control group and maintained that low level throughout the experimental period (Fig. 8). 
Table 2. Pyknotic index (\%) in rat fetal brain treated by MTX

\begin{tabular}{llcccc}
\hline & & $6 \mathrm{hr}$ & $12 \mathrm{hr}$ & $24 \mathrm{hr}$ & $36 \mathrm{hr}$ \\
\hline Telencephalon & Control & $0.03 \pm 0.03$ & $0.05 \pm 0.05$ & $0.10 \pm 0.07$ & $0.28 \pm 0.14$ \\
& MTX & $2.68 \pm 0.85$ & $19.98 \pm 2.45^{\dagger \dagger}$ & $34.82 \pm 2.17^{\dagger \dagger \dagger}$ & $43.33 \pm 3.07^{\dagger \dagger \dagger}$ \\
Diencephalon & Control & $0.61 \pm 0.28$ & $0.79 \pm 0.30$ & $0.66 \pm 0.36$ & $0.81 \pm 0.30$ \\
& MTX & $1.61 \pm 0.38$ & $14.31 \pm 1.53^{\dagger \dagger}$ & $20.88 \pm 2.44^{\dagger \dagger}$ & $20.65 \pm 1.67^{\dagger \dagger}$ \\
Mesencephalon & Control & $0.39 \pm 0.04$ & $0.41 \pm 0.11$ & $0.29 \pm 0.11$ & $0.47 \pm 0.12$ \\
& MTX & $0.37 \pm 0.18$ & $7.78 \pm 2.88$ & $26.90 \pm 5.45^{\dagger}$ & $36.56 \pm 3.99^{\dagger \dagger}$ \\
Metencephalon & Control & $0.00 \pm 0.00$ & $0.00 \pm 0.00$ & $0.00 \pm 0.00$ & $0.07 \pm 0.05$ \\
& MTX & $0.04 \pm 0.02$ & $0.00 \pm 0.00$ & $2.34 \pm 1.52$ & $3.88 \pm 0.72^{\dagger}$ \\
\hline
\end{tabular}

Values are expressed as means \pm SE (\%). $\dagger, \uparrow \dagger$, $\dagger \dagger$ : Significantly different from control at $P<0.05$, $P<0.01, P<0.001$ respectively (Welch's $t$-test).

Table 3. Mitotic index (\%) in rat fetal brain treated by MTX

\begin{tabular}{llllll}
\hline & \multicolumn{1}{c}{$6 \mathrm{hr}$} & \multicolumn{1}{c}{$12 \mathrm{hr}$} & \multicolumn{1}{c}{$24 \mathrm{hr}$} & \multicolumn{1}{c}{$36 \mathrm{hr}$} \\
\hline Telencephalon & Control & $4.56 \pm 0.20$ & $4.48 \pm 0.25$ & $4.82 \pm 0.24$ & $4.50 \pm 0.09$ \\
& MTX & $0.53 \pm 0.05^{\dagger \dagger \dagger}$ & $0.24 \pm 0.03^{\dagger \dagger \dagger}$ & $0.16 \pm 0.08^{* * *}$ & $0.22 \pm 0.13^{* * *}$ \\
Diencephalon & Control & $3.01 \pm 0.28$ & $3.30 \pm 0.33$ & $2.56 \pm 0.36$ & $3.66 \pm 0.28$ \\
& MTX & $0.37 \pm 0.08^{* * *}$ & $0.57 \pm 0.09^{* * *}$ & $0.37 \pm 0.09^{\dagger \dagger}$ & $0.40 \pm 0.20^{* * *}$ \\
Mesencephalon & Control & $3.64 \pm 0.43$ & $3.76 \pm 0.35$ & $3.51 \pm 0.44$ & $4.53 \pm 0.34$ \\
& MTX & $0.64 \pm 0.17^{* * *}$ & $0.96 \pm 0.10^{* * *}$ & $0.22 \pm 0.07^{\dagger \dagger}$ & $1.13 \pm 0.27^{* * *}$ \\
Metencephalon & Control & $3.12 \pm 0.64$ & $3.25 \pm 0.25$ & $1.37 \pm 0.25$ & $1.25 \pm 0.10$ \\
& MTX & $0.67 \pm 0.08^{\dagger}$ & $1.40 \pm 0.35^{* *}$ & $1.53 \pm 0.47$ & $1.60 \pm 0.26$ \\
\hline
\end{tabular}

Values are expressed as means \pm SE (\%). ${ }^{* *}, * * *$ : Significantly different from control at $P<0.01$, $P<0.001$ respectively (Student's $t$-test). $\dagger, \dagger \dagger, \dagger \dagger \dagger$ : Significantly different from control at $P<0.05$, $P<0.01, P<0.001$ respectively (Welch's $t$-test).

In the MTX-treated group, pyknotic indices of telencephalon and diencephalon significantly increased at 12-36 $\mathrm{hr}$, and those of the mesencephalon significantly increased at 24 and $36 \mathrm{hr}$, compared to the control group (Table 2). The pyknotic index of metencephalon significantly increased at $36 \mathrm{hr}$ compared to control group, and it showed a clearly lower value, compared to those of the telencephalon, diencephalon and mesencephalon (Table 2). In the MTX-treated group, there were fewer pyknotic neuroepithelial cells in the metencephalon than in the telencephalon, diencephalon and mesencephalon. In the MTX-treated group, while mitotic indices of telencephalon, diencephalon and mesencephalon decreased significantly at 6-36 hr, that of metencephalon decreased significantly at 6 and $12 \mathrm{hr}$ compared to the control group (Table 3).

\section{DISCUSSION}

It has been reported that microcephaly can occur as one of the central nervous system anomalies of MTX embryopathy in humans $[1,8]$. The pathogenesis of microcephaly was closely associated with excessive neuronal death [7, 31,38]. The cause of MTX-induced microcephaly may be also associated with excessive neuronal death. In the present study, the majority of pyknotic neuroepithelial cells in the telencephalic wall were positive for TUNEL staining and cleaved caspase-3. Cleavage of caspase-3 is known to be involved in cell apoptosis and is recognized as an apoptosis marker [10]. These results indicate that pyknotic changes induced by MTX in the present study are caused by apoptosis. In the present study, pyknotic neuroepithelial cells in the telencephalon at $6 \mathrm{hr}$ were positive for cleaved caspase-3, but negative for TUNEL staining. This result may reflect that the cleavage of caspase-3 precedes DNA fragmentation in the process of the neuroepithelial cell apoptosis induced by MTX.

The previous studies showed that DNA-damaging chemical administration at GD 12 or 13 induces apoptosis in neuroepithelial cells of the telencephalic wall of fetal brain [19-21, 28, 30, 39-42]. These apoptotic neuroepithelial cells are mainly observed in the dorsal layer after treatment with ENU $[6,19-21]$ in the medial to dorsal layer after treatment with hydroxyurea [41], 5-Fu [6, 42], busulfan [30] and etoposide [28] and in the ventral to medial layers after treatment with $5 \mathrm{AzC}[6,39,40]$. In the present study, apoptotic neuroepithelial cells localized throughout all layers of the telencephalic wall, but their distribution was different from those of apoptotic neuroepithelial cells induced by the above-mentioned other DNA-damaging chemicals (Table 4). It is known that in the ventricular zone of fetal brain, the positions of the nuclei of neuroepithelial cells are correlated with their cell cycle phase [6]. S-phase nuclei are located in the dorsal layer of the ventricular zone [6]. They migrate inward during the $\mathrm{G} 2$ phase, and mitosis occurs at the ventricular surface [6]. Then, they migrate outward during the G1 phase and enter the S phase again [6]. In brief, the nuclei during the G1 or G2 phase are in the middle layer of the ventricular zone. The distribution of apoptotic neuroepithelial cells throughout all layers of the telencephalic wall in the present study may reflect that MTX induces apoptosis 
Table 4. Location of apoptotic cells in the ventricular zone of telencephalon after treatment with DNA-damaging chemicals

\begin{tabular}{ll}
\hline & Location of apoptotic cells in the ventricular zone of telencephalon \\
\hline Ethylnitrosourea & Dorsal layer \\
Hydroxyurea, Busulfan, Etoposide, 5-Fluorouracil & Medial to dorsal layers \\
5-Azacytidine & Ventral to medial layers \\
\hline Methotrexate & All layers \\
\hline
\end{tabular}

Table 5. Timing of the maximal level of cell death indices and minimal level of cell proliferation indices in the telencephalon after DNA-damaging chemicals treatment

\begin{tabular}{lccccc}
\hline & \multicolumn{3}{c}{ Maximal level of cell death indices } & \multicolumn{2}{c}{ Minimal level of cell proliferation indices } \\
\cline { 2 - 6 } & Pyknosis & TUNEL & Cleaved caspase-3 & Mitosis & Phospho-histone H3 \\
\hline 1-ß-D-arabinofuranosylcytosine & $9 \mathrm{hr}$ & - & - & - & - \\
Ethylnitrosourea & $12 \mathrm{hr}$ & - & - & - & - \\
T-2 toxin & - & $12 \mathrm{hr}$ & - & - & - \\
5-azacytide & - & $12 \mathrm{hr}$ & - & $24 \mathrm{hr}$ & - \\
Busulfan & - & - & $48 \mathrm{hr}$ & - & $48 \mathrm{hr}$ \\
6-Mercaptopurine & - & - & - & $36 \mathrm{hr}$ & $36 \mathrm{hr}$ \\
\hline Methotrexate & $36 \mathrm{hr}$ & $36 \mathrm{hr}$ & $36 \mathrm{hr}$ & $6-36 \mathrm{hr}$ & $6-36 \mathrm{hr}$ \\
\hline
\end{tabular}

of neuroepithelial cells in all phases of the cell cycle or that apoptosis occurs independently of cell cycle arrest. Whereas a previous study showed that apoptosis of the human hepatoma HepG2 cells induced by folate deficiency was specific for S- and/or G2-phase arrest [13], the present result suggests that MTX induces apoptosis of neuroepithelial cells through a mechanism other than S- and/or G2-phase arrest.

In the present study, the pyknotic, TUNEL and cleaved caspase- 3 indices of neuroepithelial cells in the telencephalon peaked $36 \mathrm{hr}$ after treatment with MTX at GD 13 (Table 5). The index of pyknotic cells in the telencephalon peaked 9-12 hr after treatment with Ara-C [43] and ENU [19]. The index of TUNEL-positive cells peaked $12 \mathrm{hr}$ after treatment with $\mathrm{T}-2$ toxin and $5 \mathrm{AzC}[34,39]$, and the index of cleaved caspse-3-positive cells peaked $48 \mathrm{hr}$ after treatment with busulfan [30]. On the other hand, in the present study, mitotic and phospho-histone $\mathrm{H} 3$ indices in telencephalon treated with MTX decreased significantly at $6 \mathrm{hr}$ and maintained that low level throughout the experimental period (Table 5). The mitotic cell index in the telencephalon significantly decreased at $30 \mathrm{hr}$ and reached its lowest level $36 \mathrm{hr}$ after treatment with 6-MP [17], while the mitotic cell index peaked 6 $\mathrm{hr}$, decreased thereafter and reached the minimal level 24 hr after treatment with $5 \mathrm{AzC}[40]$. The index of phosphohistone H3-positive cells significantly decreased at $24 \mathrm{hr}$ and reached its minimal level $48 \mathrm{hr}$ after treatment with busulfan [30], while it reached the lowest level $36 \mathrm{hr}$ after treatment with 6-MP [18]. The distribution of pyknotic neuroepithelial cells and the time-course changes of the indices of pyknotic and mitotic neuroepithelial cells in the telencephalic wall were different from those of the previously-mentioned other DNA-damaging chemicals. These differences may reflect the disparity in mechanisms of apoptosis and the inhibition of cell proliferation in neuroepithelial cells among DNAdamaging chemicals. Further investigations should be con- ducted to clarify the true cause of these differences.

In the present study, MTX induced fewer pyknotic changes of neuroepithelial cells in the metencephalon than in other brain regions. The result of a previous study suggested that cell-proliferative activity was associated with the sensitivity to MTX [37]. The different pyknotic indices of the MTX-treated group among the brain regions in the present study may reflect the disparity of cell-proliferative activity. In a previous study [44], MTX inhibited the development of individual brain parts to varying degrees in chick embryos. The same study suggested that the different effects of MTX on various brain parts may be due to different schedules of cell proliferation among individual brain parts. Other previous studies demonstrated that busulfan or $5-\mathrm{Fu}$ treatment at GD13 in rat fetus induced pyknotic changes of neuroepithelial cells in metencephalon to the same degree as those in diencephalon and mesencephalon [29, 42]. These results suggest that there are differences in sensitivities to MTX, busulfan and 5-Fu of neuroepithelial cells in the metencephalon.

There are several studies describing brain malformation induced by MTX in human and rabbits [2, 16, 35]. A report of Seidahmed et al. [35] described that $2.5 \mathrm{mg}$ of MTX 3 times a day for 7 days, for a total of $52.5 \mathrm{mg}$ at 6 weeks of gestation, induced alobar holoprosencephaly, cerebellar hypoplasia and agenesis of the corpus callosum in human. Corona-Rivera et al. [2] reported that MTX $5 \mathrm{mg} /$ day treatment for 14 days at the 5 th week post-conception induced brain anomalies including semilobar holoprosencephaly and hydrocephalus in human. In rabbits, MTX $19.2 \mathrm{mg} / \mathrm{kg}$ administration during GD 10-15 induced various anomalies including hydrocephalus [16]. In the present study, single dose-administration of MTX $30 \mathrm{mg} / \mathrm{kg}$ on GD 13 induced fetal death $48 \mathrm{hr}$ after treatment, and the cause of fetal death in the present study may be relevant to dose, number and 
timing of MTX administration.

In conclusion, MTX administration of $30 \mathrm{mg} / \mathrm{kg}$ on GD 13 induced apoptosis of neuroepithial cells and inhibited mitosis of these cells in telencephalon 6-36 hr after treatment. The distribution of apoptotic neuroepithelial cells in the telencephalic wall and the whole brain and the time-course changes of the indices of apoptotic and mitotic neuroepithelial cells were different from other DNA-damaging chemicals reported previously. While the detailed mechanisms of MTXinduced neuroepithelial cell damage in fetal brain remain unclear, the present results provide fundamental information about the fetal brain damage induced by MTX. The present results serve to elucidate the pathogenesis of nervous system anomalies resulting from failed pregnancy termination with MTX or when mothers who are taking MTX for medical reasons become pregnant inadvertently. To our knowledge, this is the first report demonstrating histopathological findings of fetal brain damage induced by MTX.

\section{REFERENCES}

1. Bawle, E. V., Conard, J. V. and Weiss, L. 1998. Adult and two children with fetal methotrexate syndrome. Teratology 57: 51-55. [Medline] [CrossRef]

2. Corona-Rivera, J. R., Rea-Rosas, A., Santana-Ramírez, A., Acosta-León, J., Hernández-Rocha, J. and Miguel-Jiménez, K. 2010. Holoprosencephaly and genitourinary anomalies in fetal methotrexate syndrome. Am. J. Med. Genet. A 152: 1741-1746. [Medline] [CrossRef]

3. Cuellar, M. L. and Espinoza, L. R. 1997. Methotrexate use in psoriasis and psoriatic arthritis. Rheum. Dis. Clin. North Am. 23: 797-809. [Medline] [CrossRef]

4. DeLoia, J. A., Stewart-Akers, A. M. and Creinin, M. D. 1998. Effects of methotrexate on trophoblast proliferation and local immune responses. Hum. Reprod. 13: 1063-1069. [Medline] [CrossRef]

5. DeSesso, J. M. and Goeringer, G. C. 1992. Methotrexateinduced developmental toxicity in rabbits is ameliorated by 1-(p-tosyl)-3,4,4-trimethylimidazolidine, a functional analog for tetrahydrofolate-mediated one-carbon transfer. Teratology 45: 271-283. [Medline] [CrossRef]

6. Doi, K. 2011. Mechanisms of neurotoxicity induced in the developing brain of mice and rats by DNA-damaging chemicals. $J$. Toxicol. Sci. 36: 695-712. [Medline] [CrossRef]

7. Furukawa, S., Abe, M., Usuda, K. and Ogawa, I. 2004. Indole3 -acetic acid induces microencephaly in rat fetuses. Toxicol. Pathol. 32: 659-667. [Medline] [CrossRef]

8. Garcia-Minaur, S. and Botella, M. P. 2000. Further case of aminopterin syndrome sine aminopterin in a Spanish child. Am. J. Med. Genet. 95: 320-324. [Medline] [CrossRef]

9. Genestier, L., Paillot, R., Quemeneur, L., Izeradjene, K. and Revillard, J. P. 2000. Mechanisms of action of methotrexate. Immunopharmacology 47: 247-257. [Medline] [CrossRef]

10. Gown, A. M. and Willingham, M. C. 2002. Improved detection of apoptotic cells in archival paraffin sections: immunohistochemistry using antibodies to cleaved caspase 3. J. Histochem. Cytochem. 50: 449-454. [Medline] [CrossRef]

11. Herman, S., Zurgil, N. and Deutsch, M. 2005. Low dose methotrexate induces apoptosis with reactive oxygen species involvement in $\mathrm{T}$ lymphocytic cell lines to a greater extent than in monocytic lines. Inflamm. Res. 54: 273-280. [Medline]
[CrossRef]

12. Hiraga, S., Arita, N., Ohnishi, T., Kohmura, E., Yamamoto, K., Oku, Y., Taki, T., Sato, M., Aozasa, K. and Yoshimine, T. 1999. Rapid infusion of high-dose methotrexate resulting in enhanced penetration into cerebrospinal fluid and intensified tumor response in primary central nervous system lymphomas. J. Neurosurg. 91: 221-230. [Medline] [CrossRef]

13. Huang, R. F., Ho, Y. H., Lin, H. L., Wei, J. S. and Liu, T. Z. 1999. Folate deficiency induces a cell cycle-specific apoptosis in HepG2 cells. J. Nutr. 129: 25-31. [Medline]

14. Hyoun, S. C., Običan, S. G. and Scialli, A. R. 2012. Teratogen update: methotrexate. Birth Defects Res. Part A Clin. Mol. Teratol. 94: 187-207. [Medline] [CrossRef]

15. Johnson, F. E., Farr, S. A., Mawad, M. and Woo, Y. C. 1994. Testicular cytotoxicity of intravenous methotrexate in rats. $J$ Surg Oncol. 55: 175-178. [Medline] [CrossRef]

16. Jordan, R. L., Wilson, J. G. and Schumacher, H. J. 1977. Embryotoxicity of the folate antagonist methotrexate in rats and rabbits. Teratology 15: 73-79. [Medline] [CrossRef]

17. Kanemitsu, H., Yamauchi, H., Komatsu, M., Yamamoto, S., Okazaki, S. and Nakayama, H. 2009a. Time-course changes in neural cell apoptosis in the rat fetal brain from dams treated with 6-mercaptopurine (6-MP). Histol. Histopathol. 24: 317-324. [Medline]

18. Kanemitsu, H., Yamauchi, H., Komatsu, M., Yamamoto, S., Okazaki, S., Uchida, K. and Nakayama, H. 2009b. 6-Mercaptopurine (6-MP) induces cell cycle arrest and apoptosis of neural progenitor cells in the developing fetal rat brain. Neurotoxicol. Teratol. 31: 104-109. [Medline] [CrossRef]

19. Katayama, K., Uetsuka, K., Ishigami, N., Nakayama, H. and Doi, K. 2001. Apoptotic cell death and cell proliferative activity in the rat fetal central nervous system from dams administered with ethylnitrosourea (ENU). Histol. Histopathol. 16: 79-85. [Medline]

20. Katayama, K., Ishigami, N., Uetsuka, K., Nakayama, H. and Doi, K. 2000. Ethylnitrosourea (ENU)-induced apoptosis in the rat fetal tissues. Histol. Histopathol. 15: 707-711. [Medline]

21. Katayama, K., Ueno, M., Yamauchi, H., Nagata, T., Nakayama, H. and Doi, K. 2005. Ethylnitrosourea induces neural progenitor cell apoptosis after S-phase accumulation in a p53-dependent manner. Neurobiol. Dis. 18: 218-225. [Medline] [CrossRef]

22. Kobayashi, K., Terada, C. and Tsukamoto, I. 2002. Methotrexate-induced apoptosis in hepatocytes after partial hepatectomy. Eur. J. Pharmacol. 438: 19-24. [Medline] [CrossRef]

23. Komatsu, K., Takada, G., Uemura, K., Shishido, F. and Kanno, I. 1990. Decrease in cerebral metabolic rate of glucose after highdose methotrexate in childhood acute lymphocytic leukemia. Pediatr. Neurol. 6: 303-306. [Medline] [CrossRef]

24. Kozma, C. and Ramasethu, J. 2011. Methotrexate and misoprostol teratogenicity: further expansion of the clinical manifestations. Am. J. Med. Genet. A 155: 1723-1728. [Medline] [CrossRef]

25. Lipscomb, G. H. 2007. Medical therapy for ectopic pregnancy. Semin. Reprod. Med. 25: 93-98. [Medline] [CrossRef]

26. Lloyd, M. E., Carr, M., McElhatton, P., Hall, G. M. and Hughes, R. A. 1999. The effects of methotrexate on pregnancy, fertility and lactation. QJM 92: 551-563. [Medline] [CrossRef]

27. Müller, M., Strand, S., Hug, H., Heinemann, E. M., Walczak, H., Hofmann, W. J., Stremmel, W., Krammer, P. H. and Galle, P. R. 1997. Drug-induced apoptosis in hepatoma cells is mediated by the CD95 (APO-1/Fas) receptor/ligand system and involves activation of wild-type p53. J. Clin. Invest. 99: 403-413. [Medline] [CrossRef]

28. Nam, C., Woo, G. H., Uetsuka, K., Nakayama, H. and Doi, K. 
2006. Histopathological changes in the brain of mouse fetuses by etoposide-administration. Histol. Histopathol. 21: 257-263. [Medline]

29. Ohira, T., Ando, R., Andoh, R., Nakazawa, T., Nishihara, K., Yamamoto, S., Nakamura, N. and Tamura, K. 2009. Distribution and sequence of pyknotic cells in rat fetuses exposed to busulfan. J. Toxicol. Pathol. 22: 167-171. [Medline] [CrossRef]

30. Ohira, T., Ando, R., Okada, Y., Suzuki, H., Saito, T., Nakazawa, T., Nishihara, K., Yamamoto, S., Nakamura, N. and Tamura, K. 2013. Sequence of busulfan-induced neural progenitor cell damage in the fetal rat brain. Exp. Toxicol. Pathol. 65: 523-530. [Medline] [CrossRef]

31. Passemard, S., Kaindl, A. M. and Verloes, A. 2013. Microcephaly. Handb. Clin. Neurol. 111: 129-141. [Medline]

32. Pisarska, M. D., Carson, S. A. and Buster, J. E. 1998. Ectopic pregnancy. Lancet 351: 1115-1120. [Medline] [CrossRef]

33. Practice Committee of American Society for Reproductive Medicine 2008. Medical treatment of ectopic pregnancy. Fertil. Steril. 90: S206-S212. [Medline] [CrossRef]

34. Sehata, S., Kiyosawa, N., Makino, T., Atsumi, F., Ito, K., Yamoto, T., Teranishi, M., Baba, Y., Uetsuka, K., Nakayama, H. and Doi, K. 2004. Morphological and microarray analysis of T-2 toxin-induced rat fetal brain lesion. Food Chem. Toxicol. 42: 1727-1736. [Medline] [CrossRef]

35. Seidahmed, M. Z., Shaheed, M. M., Abdulbasit, O. B., Al Dohami, H., Babiker, M., Abdullah, M. A. and Abomelha, A. M. 2006. A case of methotrexate embryopathy with holoprosencephaly, expanding the phenotype. Birth Defects Res. Part A Clin. Mol. Teratol. 76: 138-142. [Medline] [CrossRef]

36. Spurlock, C. F. 3rd., Tossberg, J. T., Fuchs, H. A., Olsen, N. J. and Aune, T. M. 2012. Methotrexate increases expression of cell cycle checkpoint genes via JNK activation. Arthritis Rheum. 64:
1780-1789. [Medline] [CrossRef]

37. Sun, J., Sugiyama, A., Inoue, S., Takeuchi, T., Takeuchi, T. and Furukawa, S. 2013. Effect of methotrexate on rat placenta development. Exp. Toxicol. Pathol. 65: 995-1002. [Medline] [CrossRef]

38. Takano, T., Akahori, S., Takeuchi, Y. and Ohno, M. 2006. Neuronal apoptosis and gray matter heterotopia in microcephaly produced by cytosine arabinoside in mice. Brain Res. 1089: 55-66. [Medline] [CrossRef]

39. Ueno, M., Katayama, K., Nakayama, H. and Doi, K. 2002a. Mechanisms of 5-azacytidine (5AzC)-induced toxicity in the rat foetal brain. Int. J. Exp. Pathol. 83: 139-150. [Medline] [CrossRef]

40. Ueno, M., Katayama, K., Yasoshima, A., Nakayama, H. and Doi, K. 2002b. 5-Azacytidine (5AzC)-induced histopathological changes in the central nervous system of rat fetuses. Exp. Toxicol. Pathol. 54: 91-96. [Medline] [CrossRef]

41. Woo, G. H., Katayama, K., Jung, J. Y., Uetsuka, K., Bak, E. J., Nakayama, H. and Doi, K. 2003. Hydroxyurea (HU)-induced apoptosis in the mouse fetal tissues. Histol. Histopathol. 18 387-392. [Medline]

42. Yamaguchi, Y., Aoki, A., Fukunaga, Y., Matsushima, K., Ebata, T., Ikeya, M. and Tamura, K. 2009. 5 -fluorouracil-induced histopathological changes in the central nervous system of rat fetuses. Histol. Histopathol. 24: 133-139. [Medline]

43. Yamauchi, H., Katayama, K., Ueno, M., Uetsuka, K., Nakayama, H. and Doi, K. 2004. Involvement of p53 in 1-beta-D-arabinofuranosylcytosine-induced rat fetal brain lesions. Neurotoxicol. Teratol. 26: 579-586. [Medline] [CrossRef]

44. Zamenhof, S. 1985. Differential effects of antifolate on the development of brain parts in chick embryos. Growth 49: 28-33. [Medline] 